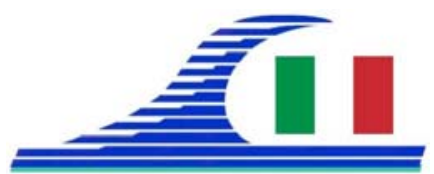

Conférence Méditerranéenne Côtière et Maritime EDITION 3, FERRARA, ITALIA (2015)

Coastal and Maritime Mediterranean Conference

Disponible en ligne - http://www.paralia.fr - Available online

\title{
The role of the Wadi Flood in the spatio-temporal sedimentary morphodynamics evolution in an arid/semi-arid beach: Wadi Ksob and Essaouira beach (Morocco)
}

\author{
Abdelhadi EL MIMOUNI ${ }^{1}$, Lahcen DAOUDI ${ }^{1}$, \\ Fatima Zahra OMDI ${ }^{1}$, Laarbi LAHMADI ${ }^{1}$, Fouad LOTFI ${ }^{2}$
}

1. Laboratoire de Géosciences et Environnement, Faculté des Sciences et TechniquesGuéliz, BP 549, Marrakech, Morocco.a.elmimouni@uca.ma

2. Iben Zouhr University. Agadir, Morocco.

\begin{abstract}
:
Located on the Moroccan Atlantic coast, the coastline of Essaouira is recognized by the existence of the outlet of Wadi Ksob catchment $\left(1480 \mathrm{Km}^{2}\right)$. Therefore, this Wadi constitutes the principal sediment sources of the Essaouira bay beach and its coastal system, especially during the period of floods. In order to understand the fate of Wadi Ksob sediment flows and its principal role in the coastline balance, and to find out the spatio-temporal sedimentary morphodynamics evolution in this semi-arid area, several topographic and hydrodynamic measurement campaigns were carried out between 2004 and 2013, using a total station and an ADCP (Acoustic Doppler current profiler).
\end{abstract}

Keywords: Coastline evolution, Widi Ksob flood, sedimentary morphodynamics, evolution, estuary.

\section{Introduction}

Coastal areas are among the most heavily populated areas around the world and are places of intensive economic development (DHARMARATNE, \& BRAITHWAITE, 1998; MARIT \& LISETTE, 2009). Therefore, Human migration tends to continue to the coast and major growths in coastal tourism have resulted in escalating investment in coastal locations.

Morocco, where coasts account for $3500 \mathrm{~km}$, is surrounded on two sides by the Mediterranean Sea in the north and the Atlantic Ocean on the western side.

The coastline of Essaouira, on the Atlantic side, is recognized by the existence of the outlet of the Wadi Ksob catchment $\left(1480 \mathrm{~km}^{2}\right)$. Therefore, Wadi Ksob floods constitute, by its sediment supply, the principal sediment sources of the Essaouira bay beach and its coastal system.

In order to know the fate of these sediments, to understand the sedimentary morphodynamics long-shore evolution of the Essaouira beach, many cross-shore beach profiles of the Essaouira beach were monitored in June 2004, June 2006 and June 2013. An additional objective of the study was also to monitor variations in the beach sediment budget following a major Wadi flooding event. 
Côtes méditerranéennes menacées :

Risques et défis dans le contexte du changement climatique

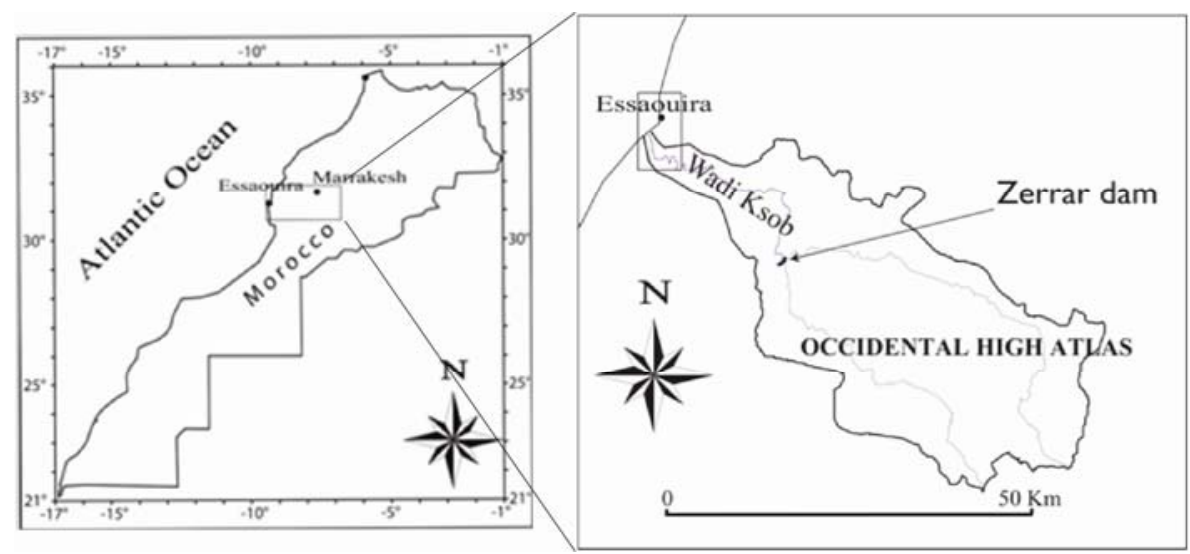

Figure 1. Study area's location.

\section{Materials and methods}

To study the characteristics of the hydrodynamism of the Essaouira bay, a hydroacoustic current meter, Acoustic Doppler Current Profiler (ADCP), was used (June and September 2006).

The evolution of beach profiles provides useful information for the scientific understanding of coastal processes and management (ANDRADE \& FERREIRA, 2006). To prevent the undergoing risks by this estuary, including the silting problem, a study of the morphosedimentary evolution of the coastal dune at the Wadi Ksob estuary has been adopted. Several topographic measurement campaigns were carried out.

\section{Results}

The flows in the Ksob basin exceeded $1000 \mathrm{~m}^{3} / \mathrm{s}$ during flood periods. It passes upon few $\mathrm{m}^{3} / \mathrm{s}$ in normal times to thousands of $\mathrm{m}^{3} / \mathrm{s}$ during floods (EL MIMOUNI, 2009; EL MIMOUNI et al., 2006 \& 2010; BAIDDAH et al., 2012), (Table 1).

Frequent Floods, which are violent and short in duration, affected the Ksob Wadi by transporting solid loads deposited in the Essaouira bay, and thus playing a fundamental role in the maintenance of the morphodynamic and sedimentary equilibrium in the river mouth and in the Essaouira beach (figure 2).

The measure undertaken in the beach shows the hydrodynamic and aerodynamic factors affecting the Essaouira bay are characterized in Figure 3 by:

i) An active incident wave, in the north and south of Essaouira city, with an interesting coastal drift towards the south. While, in the Essaouira bay, the Mogador Island and the harbour pier form obstacles to the incident wave. In fact, they are causing a very complex divergent wave in the middle of the bay.

ii) A semi-diurnal tide with south-north flood current and north south ebb current.

iii)NE currents in the north and south of the city corresponding to the coastal drift and multidirectional currents in the Middle of the Bay (EL MIMOUNI \& DAOUDI; 2012).

iv)Constant winds ( $\mathrm{N}$ to NNE 280 days/y) with variable speed depending on the season. 
Mediterranean coasts at threat:

Hazards and challenges in the context of climate variability

Table 1. Wadi Ksob Annual instantaneous maximum flows between 2003 and 2010.

\begin{tabular}{ll}
\hline Date & Flows $\left(\mathbf{m}^{3} / \mathbf{s}\right.$ \\
\hline March 2004 & 76,7 \\
November 2005 & 2550,0 \\
May 2013 & 750,0 \\
\hline
\end{tabular}
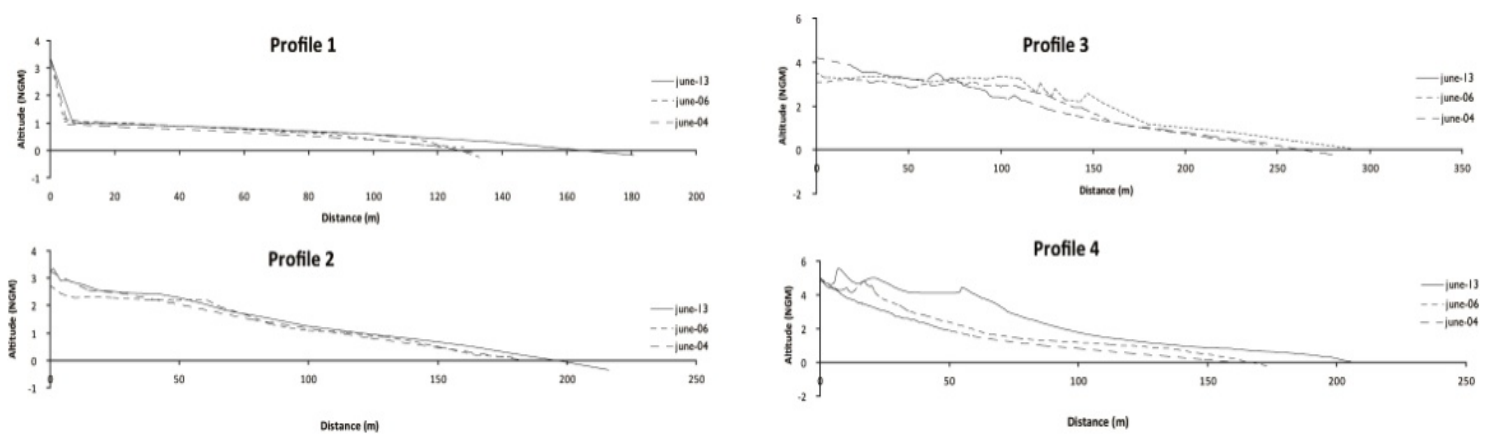

Figure 2. Essaouira beach's morphosedimentary differences between 2004, 2006 and 2013.

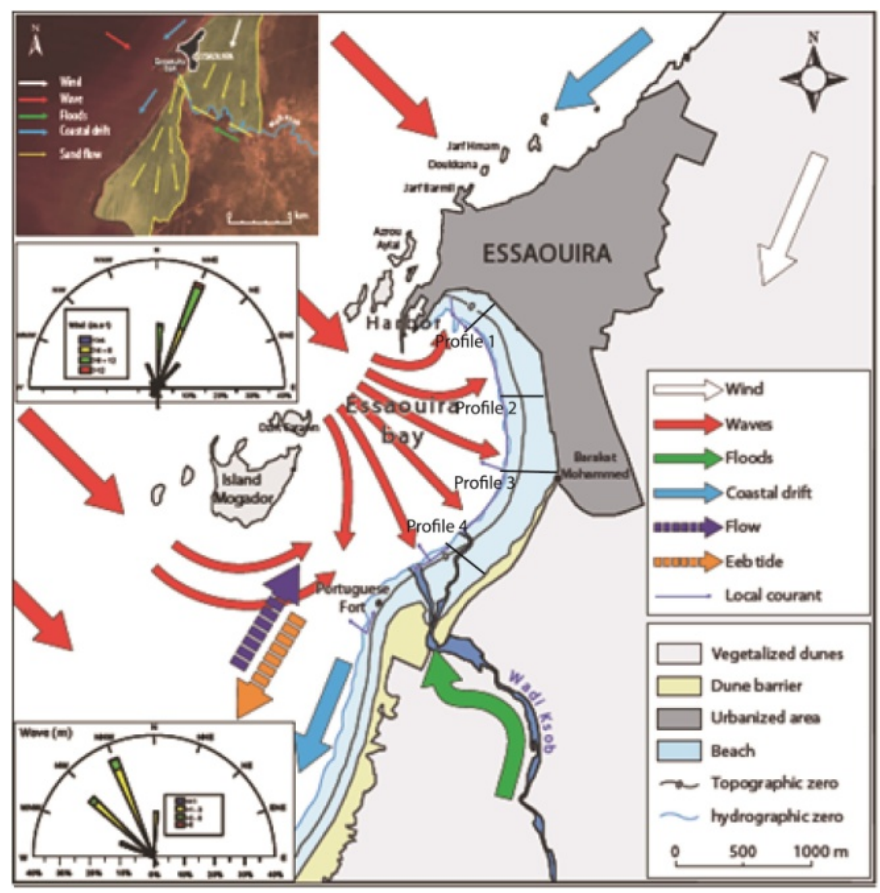

Figure 3. Characteristics of Hydrodynamics and aerodynamics factors affecting Essaouira coastline (EL MIMOUNI, 2009).

\section{Conclusion}

The Wadi Ksob plays an important role in the dynamics of the Essaouira coastline as the most important sediment source. The dominant winds from the north transport significant quantities of sand to the south in the form of barkhanes that are trapped in the estuary of the Ksob (EL MIMOUNI et al., 2014; FLOR-BLANCO et al., 2013). 
Côtes méditerranéennes menacées :

Risques et défis dans le contexte du changement climatique

During river flood events, these sands, as well as fresh inputs brought in by the wadi, are injected in the nearshore zone of the Essaouira bay, and are subsequently redistributed onshore, and along the beach by tidal currents and currents generated by refracted swell.

\section{References}

ANDRADE F., FERREIRA M.A. (2006). A Simple Method of Measuring Beach Profiles. J. of Coastal Research. Vol. 22(4), pp 995-999. http://dx.doi.org/10.2112/04-0387.1

DHARMARATNE G.S., BRAITHWAITE A.E. (1998). Economic valuation of the coastline for tourism in Barbados. Journal of Travel Research. Vol. 37(2), pp 138-144. http://dx.doi.org/10.1177/004728759803700205

BAIDDAH A., SAIDI M. E., DAOUDI L., EL MIMOUNI A., SMAIJ Z., (2012) Typologie des crues en zone montagneuse, océanique et semi aride. Le cas du bassin versant du Ksob (Haut Atlas occidental, Maroc). Larhyss Journal, n 11, pp 79-96.

EL MIMOUNI A. (2009). Approche expérimentale de suivi de la dynamique morphosédimentaire du litoral d'Essaouira, Maroc: implications pour un aménagement raisonné. Thèse de doctorat en cotutelle à l'Université du Littoral Côte d'Opale (France) et à l’Université Cadi Ayyad, Marrakech (Maroc), 259 p.

EL MIMOUNI A., DAOUDI L. (2012). Evolution à moyen terme du contexte hydrodynamique et morphosédimentaire la baie d'Essaouira (Maroc atlantique). XII ${ }^{\text {ème }}$ Journées Nationales Génie Côtier-Génie Civil, Cherbourg, pp 273-280. http://dx.doi.org/10.5150/jngcgc.2012.028-E

EL MIMOUNI A., DAOUDI L., ANTHONY E., SIPKA V., BENALI A. (2006). Dynamique sédimentaire du littoral d'Essaouira : évolution de la plage et migration dunaire. 13ème Rencontre des Géomorphologues Marocains : Espaces littoraux ; Dynamique et Gestion, Safi 18-20 mai.

EL MIMOUNI A., DAOUDI L., SAIDI M.E., BAIDDAH A. (2010). Comportement hydrologique et dynamique d'un bassin versant en milieu semi-aride: exemple du bassin versant du Ksob (Haut Atlas occidental, Maroc). Revista Cuaternario y Geomorfología, pp 99-112.

EL MIMOUNI A., DAOUDI L., ANTHONY E. (2014). Morphological change on a wadi-influenced beach: Essaouira, Morocco. Geomorphologie : relief, processus, environnement, $n^{\circ} 3$.

FLOR-BLANCO G., FLOR G., LHARTI S., PANDO L. (2013). Morphological characteristics and sand volumes of different. Coastal dune types in Essaouira Province, Atlantic Morocco. Geo-Mar Letters, Vol. 33, pp 101-115. http://dx.doi.org/10.1007/s00367-012-0318-7 MARIT B., LISETTE M. (2009). Sustainable Coastal Zone Management: A Concept for Forecasting Long-Term and Large-Scale Coastal Evolution. Journal of Coastal Research: Volume 25(1), pp 181-188. 